\title{
Epstein-Barr Virus-Associated Smooth Muscle Tumour: A Case Series with a Significant Proportion of Tumours Showing Proclivity for Cutaneous Soft Tissues
}

\author{
Tirelo M. Pitjadia, b Wayne Grayson ${ }^{a, b}$ \\ aDivision of Anatomical Pathology, School of Pathology, Faculty of Health Sciences, \\ University of the Witwatersrand, Johannesburg, South Africa; ${ }^{b}$ Ampath National \\ Laboratories, Johannesburg, South Africa
}

Keywords

Epstein-Barr virus $\cdot$ Smooth muscle tumour $\cdot$ HIV $\cdot$ Soft tissue $\cdot$ Skin

\begin{abstract}
Background: Epstein-Barr virus-associated smooth muscle tumours (EBV-SMTs) are rare neoplasms of uncertain biological potential. They are seen in the setting of immune suppression from a variety of causes, including HIV infection and post-transplant immunosuppression. Most of the literature pertaining to these neoplasms comprises case reports and small case series, with a dearth of documented cases from South Africa. Objective: To expand on the literature of these rare neoplasms in the South African context, with an emphasis on a subset showing a predilection for the cutaneous soft tissues. Method: Twentyone EBV-SMTs from 19 consecutive patients were retrieved from the archives of the Division of Anatomical Pathology in the Faculty of Health Sciences, University of the Witwatersrand, Johannesburg, and the National Health Laboratory Service. Clinical and pathological characteristics of each case were recorded, including patient age, tumour site, H\&E morphology, immunophenotypic features and the tumoural EBV status. Results: The patients' ages ranged from 12 to 63 years, with a mean of 36 years. Thirteen $(68 \%)$ of the patients in whom
\end{abstract}

Dr. T.M. Pitjadi was employed by the National Health Laboratory Service during the initial drafting of the manuscript but is currently a full-time employee of Ampath National Laboratories in Johannesburg, South Africa. 
the HIV status was known were HIV-positive. Two of the 19 patients each had 2 tumours, thus accounting for the total of 21 neoplasms studied. Although 12 of the 21 tumours (57.1\%) were from a variety of visceral organs, 9 (42.9\%) originated in the dermis and superficial subcutaneous tissues, making the cutaneous soft tissues the most commonly affected site. Morphologically, all of the neoplasms were characterised by fascicles of myoid cells, admixed rounder tumour cells, scattered intratumoural lymphocytes and variable immunohistochemical staining with markers of smooth muscle differentiation. All 21 neoplasms were proven to harbour EBV DNA. Conclusion: A significant proportion of EBVSMTs may present in the cutaneous soft tissues. This neoplasm should, therefore, be included in the histopathological differential diagnosis of any cutaneous or superficial subcutaneous spindle cell tumour, especially in patients with a history of underlying immune suppression. Accurate diagnosis thereof and its distinction from other spindle cell neoplasms is important in view of management implications and the potential for multicentricity in some patients.

\section{Introduction}

Smooth muscle cell tumours (SMTs) are among the most common soft tissue mesenchymal neoplasms. The majority of these tumours are leiomyomas, which occur predominantly in the female genital tract. Over the past two decades, however, a specific group of SMTs limited to immunocompromised patients has emerged. Although the association between SMTs and immunosuppression was first described by Pritzker et al. [1] in 1970, it was only in the 1990s that a link between these tumours and Epstein-Barr virus (EBV) was described [2,3]. The majority occur in human immunodeficiency virus (HIV)-infected people, but other groups of immunosuppressed patients may also be affected, including individuals with drug-induced immune suppression, iatrogenically immunosuppressed organ transplant recipients, and those with congenital immunodeficiency (CI) disorders [4].

Hussein et al. [5] highlighted three major clinico-pathological subtypes/groups of EBVassociated smooth muscle tumours (EBV-SMTs), namely, HIV-associated EBV-SMT, posttransplantation EBV-SMT (PT-SMT), and CI-associated EBV-SMT (CI-SMT). EBV-SMTs are rare neoplasms, with most of the literature on the entity comprising single case reports and small series. As a result, their exact frequency is unknown. It is, however, estimated that EBV-SMTs affect $1-5 \%$ of each of the 3 patient groups alluded to above [5]. Unlike other tumours such as Kaposi sarcoma (KS), where the association with HIV is well documented and the proliferation is considered to be an AIDS defining condition, the relationship between EBV-SMT and HIV is not as well studied. The latter phenomenon and the relative rarity of the tumour are perhaps reasons why the entity has thus far not been considered an AIDS defining lesion.

These tumours are purported to demonstrate a particular predilection for the central nervous system (CNS) [6-8]. Other commonly affected sites include the abdominal wall, lung, liver, gastrointestinal tract, and the soft tissues. The largest and most comprehensive series of EBV-SMTs reported from South Africa to date, however, revealed a predilection for involvement of the dermis and subcutaneous tissues of the limbs [7].

The aim of this study was to define the histomorphological and immunophenotypic characteristics of a cohort of EBV-SMTs from two major academic teaching hospitals in Greater Johannesburg, and to compare our findings with those reported from a different region of South Africa and the rest of the world. 


\section{Materials and Method}

This retrospective, cross-sectional, descriptive study was carried out in the Division of Anatomical Pathology at the University of the Witwatersrand, Johannesburg, following institutional Ethics Committee approval for the project. The study was limited to consecutive cases of EBV-SMT diagnosed histologically at the Charlotte-Maxeke Johannesburg and Chris Hani-Baragwanath Academic Hospitals between January 2013 and December 2016. The cases were identified through a manual search of the records of EBV-encoded small RNA in situ hybridisation (EBER-ISH) studies performed in the Department of Anatomical Pathology, and via a search of the laboratory's electronic database using the SNOMED code applicable to "EBV infection." The histopathology reports and glass microscopy slides from the selected cases were retrieved from the Departmental archives and reviewed. The respective patients' clinical data (including immune status), as provided by the referring clinician at the time of the initial histopathology request, were recorded. Only cases that were proven by immunohistochemistry (desmin, smooth muscle actin [SMA], muscle-specific actin [MSA], and Hcaldesmon), and molecular investigations (EBER-ISH or EBV PCR) to be EBV-SMT were included in this study. The exclusion criteria for the study included cases in which smooth muscle lineage and the presence of EBV genomic material could not be proven by one of the methods mentioned above.

The demographic and clinical details that were analysed in this study include the patient's age at presentation, gender, immune status (including CD4 count were relevant), tumour site, number of tumours and any associated symptoms. The macroscopic features that were recorded included tumour size (in centimetres) and visible necrosis, while the microscopic features analysed included tumour border, growth pattern/architecture, absence or presence of tumour necrosis, constituent tumour cell types (spindle cells with myoid morphology, second population of small rounded cells and intratumoural lymphocytes), degree of nuclear atypia, and the number of mitoses per 10 high-power fields. As already alluded to above, the immunohistochemical profile and EBV infection status of each case were also reviewed. In total, 21 neoplasms from 19 patients were reviewed, and the results are presented below.

\section{Results}

\section{Clinical Findings}

A total of 19 cases were identified, but the final number of tumours studied was 21 as 2 of the patients each harboured 2 independent EBV-SMTs. The clinical data of the selected patients are summarised in Table 1. Their ages ranged from 12 to 63 years, with a mean of 36 years. The majority were adults over the age of 20 years, with only 3 teenagers among the cohort. Eleven of the patients were female $(11 / 19 ; 57.9 \%)$, whose ages ranged from 12 to 53 years (mean, 32.1 years). Males made up 42.1\% (8/19) of the study population, and their ages ranged from 14 to 63 years (mean, 41.4 years). Of the 13 patients in whom the immune status was specified, all were seropositive for HIV infection $(13 / 19 ; 68.4 \%)$. The majority of the tumours were visceral $(12 / 2 ; 57.1 \%)$. Among the visceral tumours, there was predominant involvement of the CNS, with 6 of the 12 visceral tumours located in the CNS ( 2 in the pituitary gland, 1 in a parasellar location and 3 involving extradural paraspinal tissues). Nine $(9 / 21$; $42.9 \%$ ) of the tumours were located in the dermis and subcutaneous tissues of the back, the chest, the neck, the leg ( 2 cases), and the scapular area. The cutaneous and subcutaneous tissues, therefore, were the commonest sites of involvement. Of the 2 patients with 2 tumours each, 1 had bilateral involvement of the fallopian tubes while the other had neoplasms involving the left adrenal gland and the spleen, respectively. 
Table 1. Demographic and clinical details of 19 patients with EBV-SMTs

\begin{tabular}{clllll}
\hline $\begin{array}{l}\text { Case } \\
\text { No. }\end{array}$ & $\begin{array}{l}\text { Age, } \\
\text { years }\end{array}$ & $\begin{array}{l}\text { Gen- } \\
\text { der }\end{array}$ & $\begin{array}{l}\text { Immunosuppressive } \\
\text { disorder }\end{array}$ & Tumour site & $\begin{array}{l}\text { Tumours } \\
\text { present, } n\end{array}$ \\
\hline 1 & 44 & F & Not known & Left chest & 1 \\
2 & 23 & F & HIV, CD4 count of 225 & Right neck & 1 \\
3 & 34 & F & Not known & Right and left fallopian tubes & 2 \\
4 & 42 & M & HIV, CD4 count of 300 & Left leg & 1 \\
5 & 44 & F & HIV, CD4 count of 207 & Spleen and left adrenal gland & 2 \\
6 & 12 & F & Not known & Appendix & 1 \\
7 & 43 & M & HIV, CD4 count of 124 & Gallbladder & 1 \\
8 & 35 & M & Not known & Pituitary gland & 1 \\
9 & 63 & M & Not known & Pituitary gland & 1 \\
\hline 10 & 41 & M & HIV, CD4 count of 10 & Parasellar tumour & 1 \\
11 & 27 & F & HIV, CD4 count not known & Neck mass & 1 \\
12 & 44 & F & HIV, CD4 count not known & Thoracic spine, T3 extradural & 1 \\
& & & & tumour & \\
13 & 28 & F & HIV, CD4 count not known & Cervical spine extradural mass & 1 \\
14 & 13 & F & HIV, CD4 count not known & Left lower back & 1 \\
15 & 53 & F & HIV, CD4 count of 322 & Left thigh & 1 \\
16 & 45 & M & HIV, CD4 count of 1 & Neck & 1 \\
17 & 31 & F & HIV, CD4 count of 480 & Thoracic spine, levels T10-T12 & 1 \\
& & & & extradural mass & 1 \\
18 & 48 & M & HIV, CD4 of count 98 & Right chest wall & 1 \\
19 & 14 & M & Unknown & Scapular area & 1 \\
\hline
\end{tabular}

CD4 count expressed as cells $/ \mathrm{mm}^{3}$. M, male; F, female.

\section{Pathological Findings}

The pathological findings are summarised in Table 2. Macroscopically, the individual tumours had diameters ranging from 1.0 to $7.0 \mathrm{~cm}$ (mean, $3.6 \mathrm{~cm}$ ). Histologically, the vast majority of the tumours $(17 / 21,81.0 \%)$ showed a circumscribed border and fascicular growth of spindled myoid cells, with a nodular appearance on low-power examination (Fig. 1a, b). Necrosis was observed in only 3 tumours. Two of the latter neoplasms showed mild nuclear atypia, while the remaining case exhibited both nuclear atypia and mitotic activity, with 5 mitoses per 10 consecutive high-power fields. A characteristic second population of small rounded cells was observed in 9 (9/21, 42.9\%) of the tumours (Fig. 2). Intratumoural lymphocytes were encountered in 18 of the neoplasms $(18 / 21,85.7 \%)$. Although these lymphocytes were mainly perivascular in their distribution, some tumours harboured both perivascular and interstitial lymphocytes (Fig. 3). Twelve of the tumours showed fascicles of spindled cells within a collagenous stroma, with concomitant hyalinisation in 3 of these lesions. Six (28.6\%) of the tumours showed areas with a myxoid stroma (Fig. 4), including the neoplasms extirpated from the 2 patients who each had 2 independent EBV-SMTs. One of the latter 6 neoplasms demonstrated hypercellularity in addition to focal myxoid change (Fig. 4) but was devoid of associated cytological atypia or demonstrable mitoses.

The results of the ancillary immunohistochemical and molecular investigations are summarised in Table 3. All of the tumours showed variable myoid differentiation, as evidenced by immunohistochemical staining for desmin, H-caldesmon (Fig. 5a), SMA (Fig. 5b), and/or MSA. The most commonly expressed antigens were desmin $(17 / 21,81.0 \%)$ and SMA $(15 / 21$, 
Table 2. Pathological features of the 21 EBV-SMTs

\begin{tabular}{|c|c|c|c|c|c|c|c|c|c|c|c|}
\hline \multirow{2}{*}{$\begin{array}{l}\text { Case } \\
\text { No. }\end{array}$} & \multicolumn{2}{|c|}{ Macroscopic features } & \multicolumn{9}{|c|}{ Microscopic features } \\
\hline & $\begin{array}{l}\text { tumour size, } \\
\mathrm{cm}\end{array}$ & necrosis & border & $\begin{array}{l}\text { growth } \\
\text { pattern }\end{array}$ & necrosis & $\begin{array}{l}\text { spin- } \\
\text { dled } \\
\text { myoid } \\
\text { cells }\end{array}$ & $\begin{array}{l}\text { small } \\
\text { roun- } \\
\text { ded } \\
\text { cells }\end{array}$ & $\begin{array}{l}\text { intratumoural } \\
\text { lymphocytes }\end{array}$ & $\begin{array}{l}\text { nuclear } \\
\text { atypia }\end{array}$ & $\begin{array}{l}\text { mitoses, } \\
n\end{array}$ & other features \\
\hline 1 & 3.0 & $\mathrm{~N} / \mathrm{A}$ & Circum. & Fascicular & A & $\mathrm{P}$ & A & $\mathrm{P}$, perivascular & A & 0 & $\begin{array}{l}\text { Collagenous with } \\
\text { hyalinization }\end{array}$ \\
\hline 2 & $\mathrm{~N} / \mathrm{A}$ & $\mathrm{N} / \mathrm{A}$ & Circum. & $\begin{array}{l}\text { Nodular } \\
\text { fascicles }\end{array}$ & A & $\mathrm{P}$ & A & $\mathrm{P}$, perivascular & A & 0 & $\begin{array}{l}\text { Collagenous with } \\
\text { hyalinization }\end{array}$ \\
\hline 3 & $\begin{array}{l}4.5 \text { and } \\
2.5\end{array}$ & A & Circum. & $\begin{array}{l}\text { Nodular } \\
\text { fascicles }\end{array}$ & A & $\mathrm{P}$ & $\mathrm{P}$ & $\begin{array}{l}\mathrm{P} \text {, perivascular } \\
\text { and interstitial }\end{array}$ & $\mathrm{P}$, mild & 0 & $\begin{array}{l}\text { Collagenous stroma } \\
\text { with myxoid foci and } \\
\text { increased vascularity }\end{array}$ \\
\hline 4 & 3.5 & A & Circum. & $\begin{array}{l}\text { Nodular } \\
\text { fascicles }\end{array}$ & $\begin{array}{l}\mathrm{P}, \text { focal } \\
\text { ischaemic } \\
\text { type }\end{array}$ & $\mathrm{P}$ & $\mathrm{P}$ & $\begin{array}{l}\mathrm{P} \text {, perivascular } \\
\text { and interstitial }\end{array}$ & $\mathrm{P}$, mild & 0 & $\begin{array}{l}\text { Collagenous stroma } \\
\text { with myxoid foci }\end{array}$ \\
\hline 5 & $\begin{array}{l}\text { Spleen: } 3.8 \\
\text { Adrenal } \\
\text { gland: } 7.0\end{array}$ & A & Circum. & $\begin{array}{l}\text { Nodular } \\
\text { fascicles }\end{array}$ & A & $\mathrm{P}$ & A & $\begin{array}{l}\mathrm{P} \text {, dense inter- } \\
\text { stitial, some } \\
\text { perivascular }\end{array}$ & A & $\begin{array}{l}\text { Spleen: } 0 \\
\text { Adrenal } \\
\text { gland: } 1\end{array}$ & $\begin{array}{l}\text { Large myxoid areas } \\
\text { with collagenous foci }\end{array}$ \\
\hline 6 & $\mathrm{~N} / \mathrm{A}$ & $\mathrm{N} / \mathrm{A}$ & Circum. & $\begin{array}{l}\text { Fascicular } \\
\text { with some } \\
\text { nodules }\end{array}$ & $\mathrm{P}$ & $\mathrm{P}$ & A & A & $\mathrm{P}$, mild & 5 & \\
\hline 7 & 1.5 & A & Circum. & $\begin{array}{l}\text { Nodular } \\
\text { fascicles }\end{array}$ & $\mathrm{P}$ & $\mathrm{P}$ & $\mathrm{P}$ & $\mathrm{P}$, perivascular & A & 0 & Collagenous stroma \\
\hline 8 & $\begin{array}{l}\mathrm{N} / \mathrm{A} \text {, frag- } \\
\text { mented }\end{array}$ & $\mathrm{N} / \mathrm{A}$ & N/A & Fascicular & A & $\mathrm{P}$ & A & $\begin{array}{l}\mathrm{P}, \text { sparse } \\
\text { interstitial }\end{array}$ & A & 0 & \\
\hline 9 & $\begin{array}{l}\mathrm{N} / \mathrm{A}, \text { frag- } \\
\text { mented }\end{array}$ & A & Circum. & $\begin{array}{l}\text { Nodular } \\
\text { fascicles }\end{array}$ & A & $\mathrm{P}$ & $\mathrm{A}$ & $\mathrm{P}$ & A & 0 & Collagenous stroma \\
\hline 10 & 1.0 & A & Circum. & Fascicular & A & $\mathrm{P}$ & A & $\begin{array}{l}\mathrm{P} \text {, perivascular } \\
\text { and interstitial }\end{array}$ & $\mathrm{P}$, mild & 0 & \\
\hline 11 & $\begin{array}{l}\mathrm{N} / \mathrm{A} \text {, frag- } \\
\text { mented }\end{array}$ & $\mathrm{N} / \mathrm{A}$ & Circum. & Fascicular & A & $\mathrm{P}$ & $\mathrm{P}$ & $\begin{array}{l}\mathrm{P} \text {, perivascular } \\
\text { and interstitial }\end{array}$ & A & 0 & $\begin{array}{l}\text { Collagenous at the } \\
\text { periphery }\end{array}$ \\
\hline 12 & 2.8 & $\mathrm{~N} / \mathrm{A}$ & Circum. & $\begin{array}{l}\text { Nodular } \\
\text { fascicles }\end{array}$ & A & $\mathrm{P}$ & $\mathrm{P}$ & $\begin{array}{l}\mathrm{P} \text {, sparse } \\
\text { interstitial }\end{array}$ & A & 0 & $\begin{array}{l}\text { Collagenous with } \\
\text { hyalinization }\end{array}$ \\
\hline 13 & 4.0 & N/A & Circum. & $\begin{array}{l}\text { Nodular } \\
\text { fascicles }\end{array}$ & A & $\mathrm{P}$ & $\mathrm{P}$ & $\begin{array}{l}\mathrm{P} \text {, dense peri- } \\
\text { vascular and } \\
\text { interstitial }\end{array}$ & A & 0 & Collagenous stroma \\
\hline 14 & $\mathrm{~N} / \mathrm{A}$ & N/A & Circum. & Fascicular & A & $\mathrm{P}$ & $\mathrm{P}$ & $\mathrm{P}$, sparse & A & 0 & $\begin{array}{l}\text { Hypercellular with } \\
\text { myxoid stroma }\end{array}$ \\
\hline 15 & 6.0 & $\mathrm{~N} / \mathrm{A}$ & N/A & $\begin{array}{l}\text { Nodular } \\
\text { fascicles }\end{array}$ & A & $\mathrm{P}$ & A & $\mathrm{P}$, sparse & A & 0 & \\
\hline 16 & $\begin{array}{l}\mathrm{N} / \mathrm{A} \text {, frag- } \\
\text { mented }\end{array}$ & N/A & Circum. & Fascicular & A & $\mathrm{P}$ & $\mathrm{P}$ & $\mathrm{P}$, interstitial & A & 0 & \\
\hline 17 & $\begin{array}{l}\mathrm{N} / \mathrm{A}, \text { frag- } \\
\text { mented }\end{array}$ & $\mathrm{N} / \mathrm{A}$ & Circum. & $\begin{array}{l}\text { Nodular } \\
\text { fascicles }\end{array}$ & A & $\mathrm{P}$ & A & $\begin{array}{l}\mathrm{P} \text {, sparse } \\
\text { interstitial }\end{array}$ & A & 0 & \\
\hline 18 & N/A & N/A & $\mathrm{N} / \mathrm{A}$ & Fascicular & A & $\mathrm{P}$ & A & A & A & 0 & \\
\hline 19 & N/A & $\mathrm{N} / \mathrm{A}$ & Circum. & $\begin{array}{l}\text { Nodular } \\
\text { fascicles }\end{array}$ & A & $\mathrm{P}$ & $\mathrm{P}$ & $\mathrm{P}$ & A & 0 & \\
\hline
\end{tabular}

N/A, not applicable; P, present; A, absent; Circum., circumscribed. 

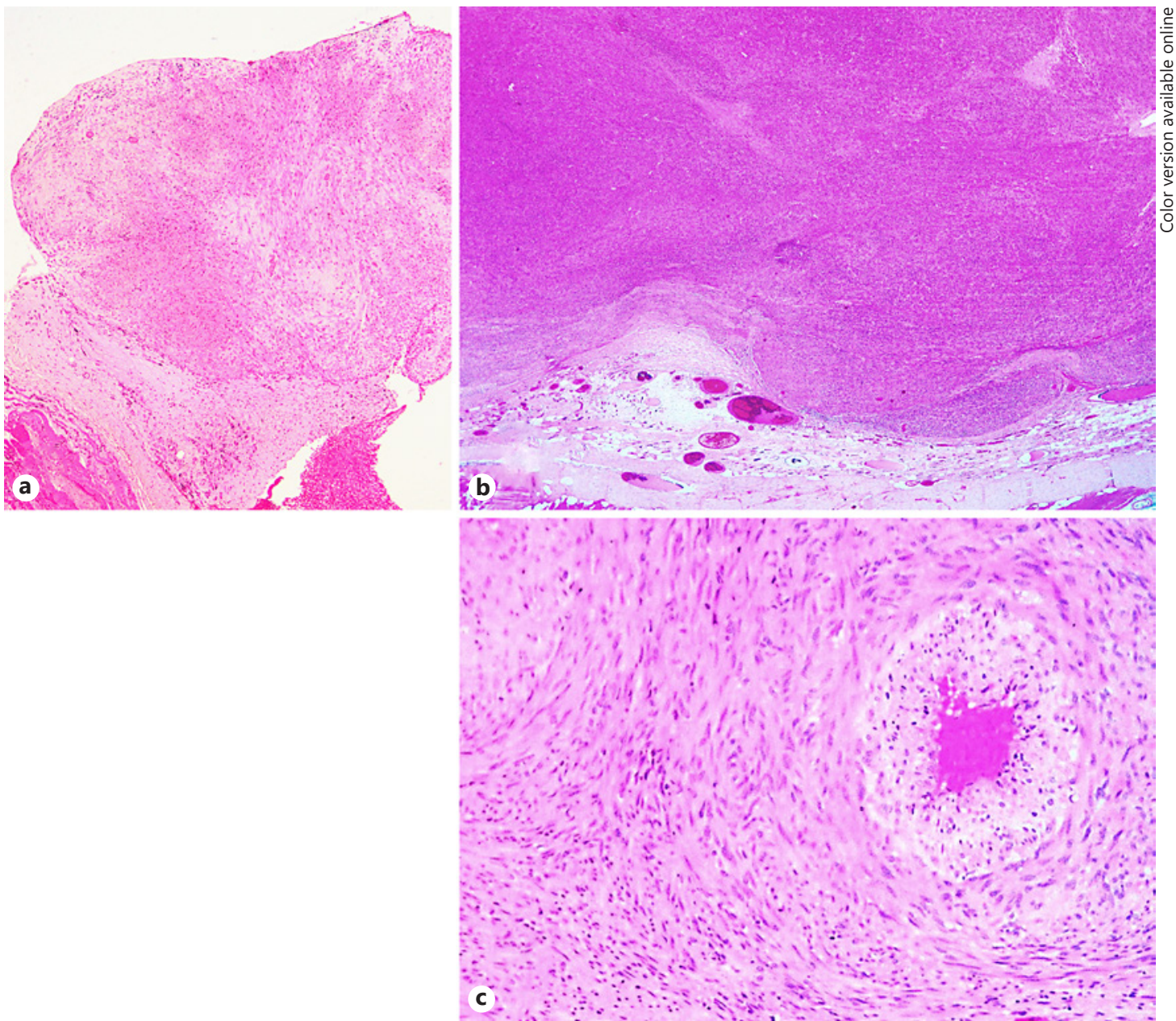

Fig. 1. EBV-SMT, with a circumscribed tumour border (a) and fascicles of myoid cells, with a nodular architecture (b). c Tumour cells in relation to a thick-walled blood vessel.

71.5\%). The presence of EBV infection was proven in all 21 tumours. EBER-ISH performed on 20 of the 21 tumours revealed strong positive nuclear signals (Fig. 5c). PCR for EBV was carried out on the remaining case and yielded a positive reaction product.

\section{Discussion}

EBV-SMTs are rare neoplasms. Consequently, most of the literature pertaining to these tumours comprises single case reports and small case series. The tumours are seen in persons affected by a variety of immunodeficiency syndromes, with a disproportionate number of them being HIV infected; this latter observation is borne out by the present study. A significant proportion of tumours, however, may evolve outside of the setting of HIV infection [4, 7]. Both adults and children are affected, with a slight female preponderance [9]. EBV-SMT is currently the second most common tumour to occur among children with AIDS $[3,10]$. Our study, however, has confirmed that in the South African setting, EBV-SMTs are predominantly tumours of adults who are immunosuppressed due to underlying HIV infection; indeed, HIV seropositivity was 
Fig. 2. a Fascicles of spindle smooth muscle cells on the right side of the field and a second population of rounded cells on the left side of the photomicrograph. $\mathbf{b}$ Another tumour showing rounded cells in the centre of the field and hyalinisation towards the bottom thereof.

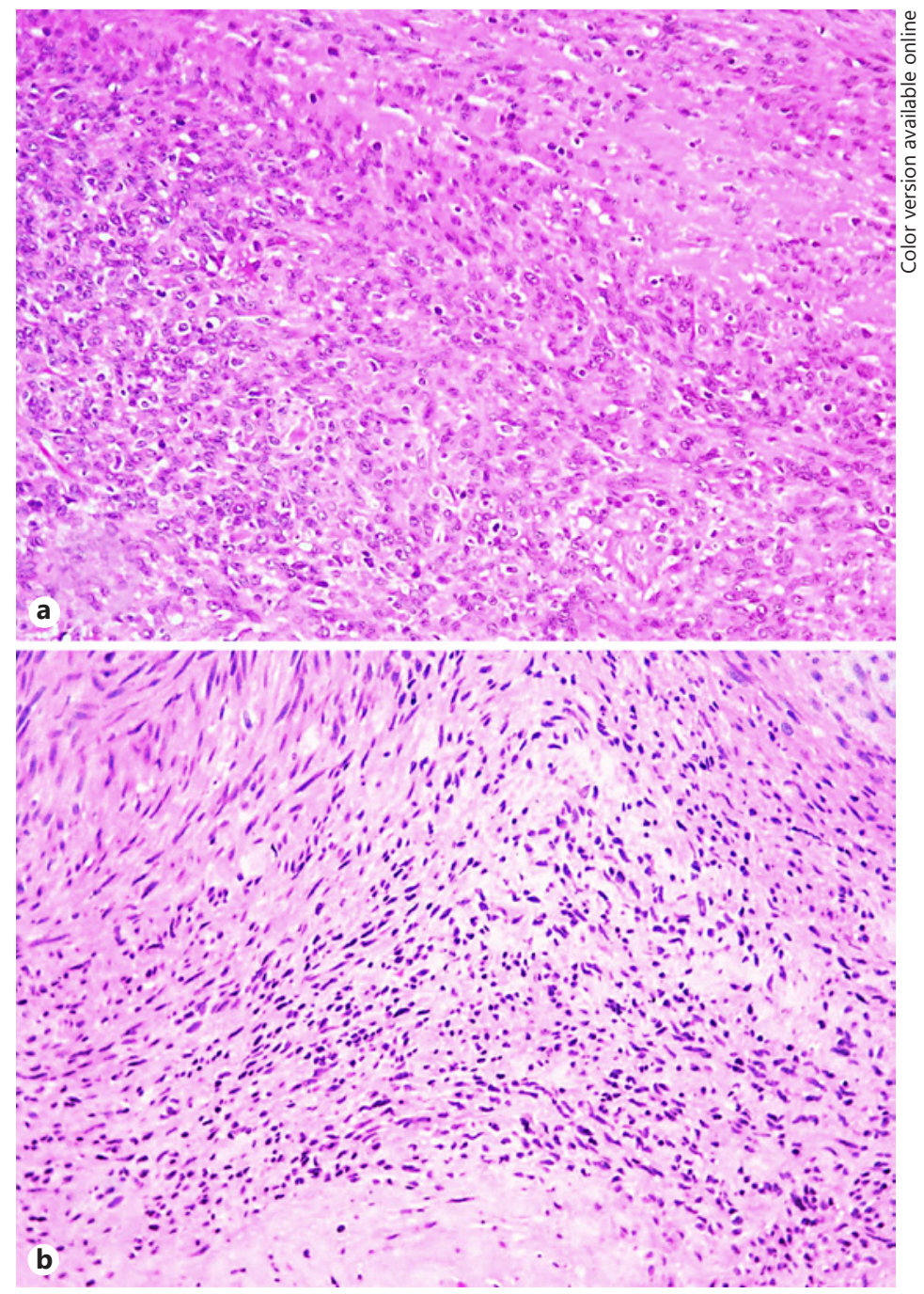

documented in all 13 patients whose HIV status was known. This unsurprising observation is a reflection of the burden of HIV disease in South Africa and corroborates the findings in a previously reported series of 27 AIDS-associated myoid tumours from this country [7]. In the latter study, the neoplasms were separated into two groups, namely, EBV-SMTs and EBV-associated myopericytomas. The majority of patients were HIV-positive adults, whose mean ages were 24.5 and 35.0 years, respectively [7]. Although most of the literature pertaining EBV-SMTs cites a particular predilection for the CNS, the majority of the tumours recorded in the aforementioned series from South Africa arose in the dermis and subcutaneous tissues, mainly of the limbs $[4,6-8]$. This observation is similar to our study in which nine $(42.9 \%)$ of the tumours were located in the dermis and subcutaneous tissues of the trunk, neck, and lower limb. It is, however, noteworthy that CNS was the second most commonly affected site in the present series $(6 / 21,28.6 \%)$. In their 2011 review article, Purgina et al. [8] found the CNS to be the most commonly affected site, followed by the soft tissues. A clinical feature peculiar to EBV-SMT is its potential multicentricity. These individual synchronous lesions are now proven to represent separate clonal events rather than metastases [4]. Multifocality, however, was encountered in only 2 of the 19 patients in the present study. 
Fig. 3. a Scattered intratumoural lymphocytes. b Admixed plasma cells are also seen at mediumpower magnification.
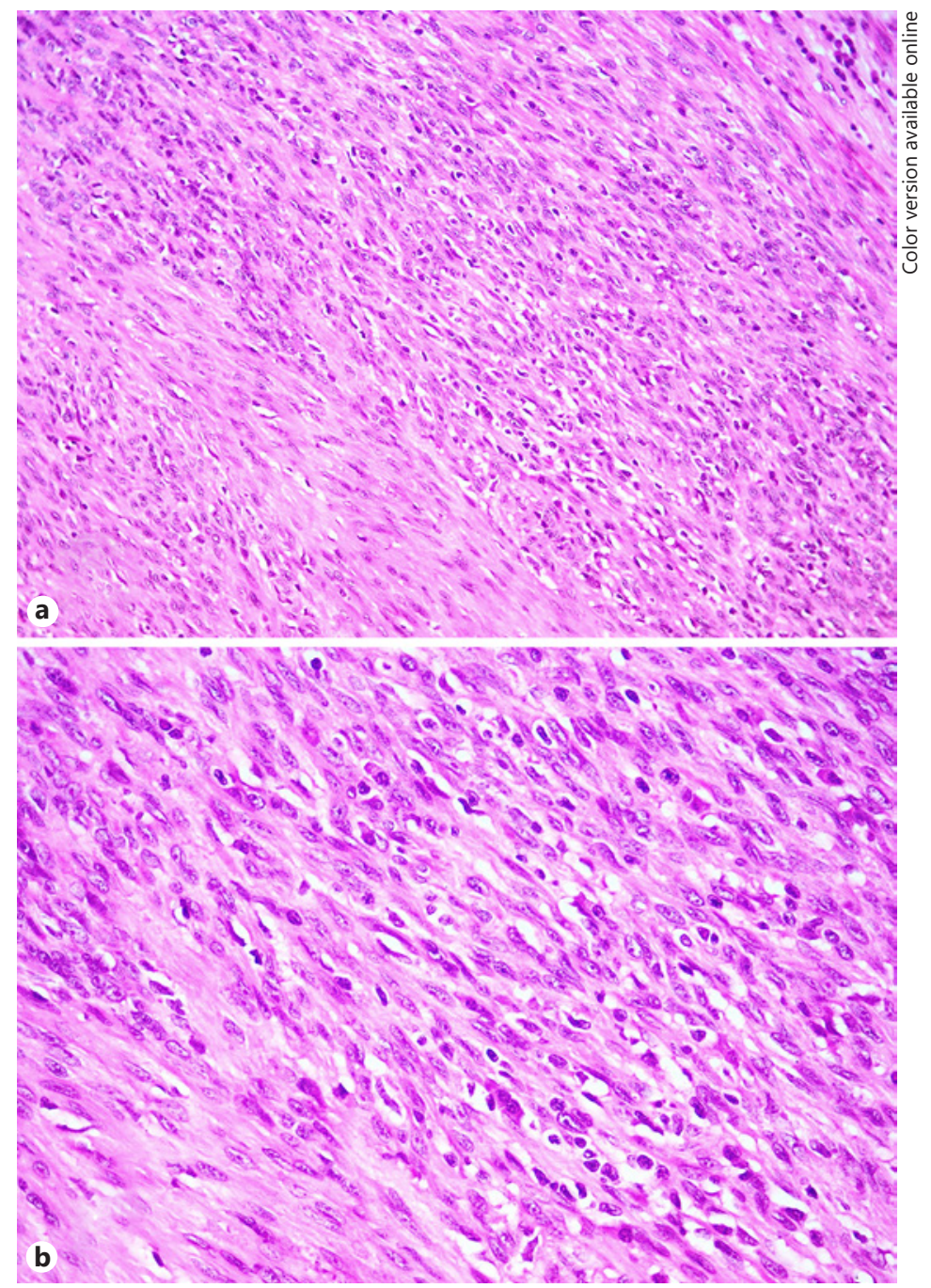

Histologically, EBV-SMTs share some features with conventional leiomyomas, such as circumscription and interdigitating fascicles of banal to mildly pleomorphic cells with brightly eosinophilic cytoplasm and "cigar-shaped" nuclei. Two additional features characteristic of EBV-SMTs, however, are (a) the presence of a second population of small, round tumour cells with irregular nuclear membranes, and (b) a contingent of intratumoural lymphocytes [1113]. A population of rounded tumour cells was encountered in only $9(42.9 \%)$ of the tumours in the present study (Fig. 2). Although these small, round cells have a proven smooth muscle phenotype, their exact significance is uncertain [4, 8]. A more consistent and characteristic finding in our study was the presence of intratumoural lymphocytes (Fig. 3), which were noted in $18(85.7 \%)$ of the tumours, predominantly in a perivascular distribution. Another feature described in the literature is a haemangiopericytoma-like vasculature, leading some authors to assign designations such as myopericytoma and angioleiomyoma to such lesions $[5,7,8,12,13]$. Only one tumour in the present series showed an increased vascularity, but its intralesional vessels exhibited slit-like lumina rather than a haemangiopericytoma-type vascular pattern. Another change described in previous studies is a myxoid stroma [4, 7]. The aforementioned phenomenon was encountered in $6(28.6 \%)$ of the tumours in the present 
Fig. 4. EBV-SMT showing both hypercellularity and central area of myxoid stroma.

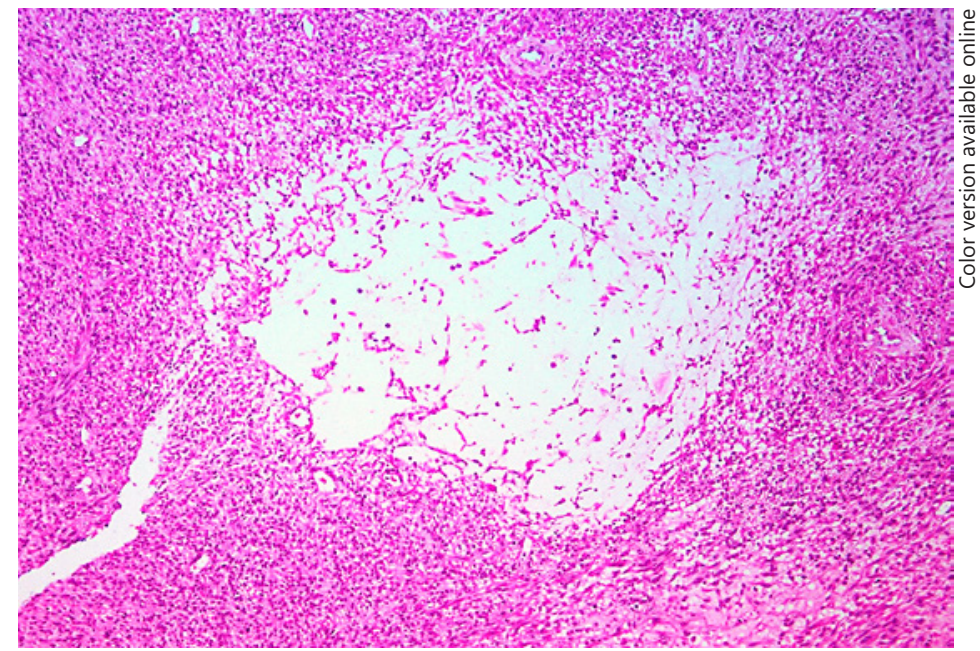

series, including those lesions removed from the 2 patients who harboured $2 \mathrm{EBV}$-SMTs each. One of these exhibited hypercellularity in addition to a myxoid stroma but was devoid of cytological atypia and mitoses. We observed no histological differences in the morphology of EBV-SMTs arising in the cutaneous soft tissues versus those occurring elsewhere.

There are reports in the literature of cases demonstrating tumour necrosis, moderate nuclear atypia, and mitotic activity; these features have been interpreted as "histological evidence of malignancy" by some authors [7]. Although one acknowledges that such an interpretation would be accurate if one were to apply the histological criteria of malignancy in conventional SMTs proposed by Billings et al. [14], it is noteworthy that these criteria were not developed to encompass EBV-SMTs per se. The latter constitute a distinct clinico-pathological entity, and conventional histological criteria for malignancy might not be predictive of their true clinical behaviour [14]. Hussein et al. [5] observed that some HIV-associated EBV-SMTs had a tendency to exhibit atypical, sarcoma-like features. In particular, the mitotic count was noted to be higher in HIV-associated EBV-SMTs than in PT-SMTs and CI-SMTs. Only 1 tumour in our series showed nuclear atypia and an elevated mitotic index. The clinical outcome in this patient, however, is unknown. EBV-SMTs have an immunohistochemical staining profile similar to that of "conventional" SMTs. Consequently, these lesions stain with antibodies to desmin, SMA, MSA, $\mathrm{H}$-caldesmon, and calponin. In our study, the preferential expression of desmin and SMA can in part be ascribed to the fact that immunohistochemical stains for $\mathrm{H}$-caldesmon and/or MSA were only requested by some pathologists during the work-up of selected cases. Since this is a retrospective cross-sectional descriptive study without specific funding, additional immunohistochemical stains could not be carried out prospectively.

EBER-ISH has emerged as the most reliable and specific method of separating EBV-SMTs from other SMTs on tissue biopsy. Other methods that have been explored include EBV DNA detection by PCR and EBV serology, but these methods are less sensitive and are therefore considered less reliable [6]. In our series, EBV-PCR was carried out on only 1 of the 21 tumours; this was necessitated by the lack of availability of EBER-ISH at the laboratory at the time of initial assessment, and an insufficient amount of remaining tissue in the paraffin wax block for later EBER-ISH analysis following completion of the initial immunohistochemical work-up and EBV-PCR.

The majority of EBV-SMTs are associated with EBV-2 infection; there is, however, one report of an EBV-1 associated SMT $[4,15]$. The progenitor cell is thought to be a smooth 
Table 3. Results of ancillary investigations, including immunohistochemistry and molecular studies

\begin{tabular}{|c|c|c|c|c|c|c|}
\hline \multirow{2}{*}{$\begin{array}{l}\text { Case } \\
\text { No. }\end{array}$} & \multicolumn{4}{|c|}{ Immunohistochemistry } & \multicolumn{2}{|c|}{ Molecular studies } \\
\hline & desmin & H-caldesmon & SMA & MSA & EBER-ISH & EBV-PCR \\
\hline 1 & $\mathrm{P}$ & $\mathrm{N} / \mathrm{P}$ & $\mathrm{P}$ & $\mathrm{P}$ & $\mathrm{P}$ & $\mathrm{N} / \mathrm{P}$ \\
\hline 2 & $\mathrm{P}$ & $\mathrm{P}$ & $\mathrm{N} / \mathrm{P}$ & $\mathrm{N} / \mathrm{P}$ & $\mathrm{P}$ & $\mathrm{N} / \mathrm{P}$ \\
\hline 3 & $\mathrm{P}$ & $\mathrm{P}$ & $\mathrm{N} / \mathrm{P}$ & $\mathrm{N} / \mathrm{P}$ & $\mathrm{P}$ & $\mathrm{N} / \mathrm{P}$ \\
\hline 4 & $\mathrm{P}$ & $\mathrm{N} / \mathrm{P}$ & $\mathrm{P}$ & $\mathrm{N} / \mathrm{P}$ & $\mathrm{P}$ & $\mathrm{N} / \mathrm{P}$ \\
\hline 5 & $\mathrm{P}$ & $\mathrm{P}$ & $\mathrm{P}$ & $\mathrm{P}$ & $\mathrm{P}$ & $\mathrm{N} / \mathrm{P}$ \\
\hline 6 & $\mathrm{P}$ & $\mathrm{P}$ & $\mathrm{P}$ & $\mathrm{P}$ & $\mathrm{P}$ & $\mathrm{N} / \mathrm{P}$ \\
\hline 7 & $\mathrm{P}$ & $\mathrm{P}$ & $\mathrm{P}$ & $\mathrm{P}$ & $\mathrm{P}$ & $\mathrm{N} / \mathrm{P}$ \\
\hline 8 & $\mathrm{P}$ & $\mathrm{N} / \mathrm{P}$ & $\mathrm{P}$ & $\mathrm{N} / \mathrm{P}$ & $\mathrm{P}$ & $\mathrm{N} / \mathrm{P}$ \\
\hline 9 & $\mathrm{~N} / \mathrm{P}$ & $\mathrm{N} / \mathrm{P}$ & $\mathrm{P}$ & $\mathrm{N} / \mathrm{P}$ & $\mathrm{P}$ & $\mathrm{N} / \mathrm{P}$ \\
\hline 10 & $\mathrm{P}$ & $\mathrm{N} / \mathrm{P}$ & $\mathrm{N} / \mathrm{P}$ & $\mathrm{N} / \mathrm{P}$ & $\mathrm{P}$ & $\mathrm{N} / \mathrm{P}$ \\
\hline 11 & $\mathrm{P}$ & $\mathrm{N} / \mathrm{P}$ & $\mathrm{P}$ & $\mathrm{N} / \mathrm{P}$ & $\mathrm{P}$ & $\mathrm{N} / \mathrm{P}$ \\
\hline 12 & $\mathrm{P}$ & $\mathrm{N} / \mathrm{P}$ & $\mathrm{P}$ & $\mathrm{N} / \mathrm{P}$ & $\mathrm{P}$ & $\mathrm{N} / \mathrm{P}$ \\
\hline 13 & $\mathrm{P}$ & $\mathrm{N} / \mathrm{P}$ & $\mathrm{N} / \mathrm{P}$ & $\mathrm{N} / \mathrm{P}$ & $\mathrm{P}$ & $\mathrm{N} / \mathrm{P}$ \\
\hline 14 & $\mathrm{~N} / \mathrm{P}$ & $\mathrm{P}$ & $\mathrm{P}$ & $\mathrm{N} / \mathrm{P}$ & $\mathrm{P}$ & $\mathrm{N} / \mathrm{P}$ \\
\hline 15 & $\mathrm{P}$ & $\mathrm{N} / \mathrm{P}$ & $\mathrm{P}$ & $\mathrm{N} / \mathrm{P}$ & $\mathrm{P}$ & $\mathrm{N} / \mathrm{P}$ \\
\hline 16 & $\mathrm{P}$ & $\mathrm{P}$ & $\mathrm{N} / \mathrm{P}$ & $\mathrm{N} / \mathrm{P}$ & $\mathrm{P}$ & $\mathrm{N} / \mathrm{P}$ \\
\hline 17 & $\mathrm{P}$ & $\mathrm{N} / \mathrm{P}$ & $\mathrm{P}$ & $\mathrm{N} / \mathrm{P}$ & $\mathrm{P}$ & $\mathrm{N} / \mathrm{P}$ \\
\hline 18 & $\mathrm{~N}$ & $\mathrm{P}$ & $\mathrm{P}$ & $\mathrm{P}$ & $\mathrm{P}$ & $\mathrm{N} / \mathrm{P}$ \\
\hline 19 & $\mathrm{~N}$ & $\mathrm{P}$ & $\mathrm{P}$ & $\mathrm{P}$ & $\mathrm{N} / \mathrm{P}$ & $\mathrm{P}$ \\
\hline
\end{tabular}

SMA, smooth muscle actin; MSA, muscle-specific actin; $\mathrm{P}$, positive; N, negative; N/P, not performed; EBV-PCR, Epstein-Barr virus polymerase chain reaction; EBER-ISH, Epstein-Barr virus-encoded small RNA in situ hybridization.

muscle cell of vascular origin, and it is hypothesised that EBV infects the smooth muscle cells in a similar manner to B-lymphocytes, via its interaction with the CD21 receptor. This assumption, however, may not necessarily be accurate as it is possible that the virus uses different receptors to gain entry into a variety of cell types $[4,12]$. In addition, some studies have failed to demonstrate the presence of CD21 receptors on the neoplastic cells of posttransplant EBV-SMTs, while others have shown the presence of a similar or related protein. It is, therefore, possible that the virus uses a different mechanism and/or receptor to induce neoplasia in PT-SMTs $[3,12,16]$. It is nevertheless plausible that the conflicting CD21 immunohistochemistry results might be due to the use of differing anti-CD21 monoclonal antibodies employed in these studies. Others have also suggested an interaction between smooth muscle cells and infected B-lymphocytes prior to tumour proliferation [8]. In lymphomas, EBV induces cellular proliferation by expressing the transforming protein LMP1, which in turn causes upregulation of the anti-apoptotic protein Bcl-2. However, LMP1 is not expressed in a majority of EBV-SMTs, and this postulated mechanism of neoplastic transformation has thus been disputed $[2,12]$. Although the data concerning expression of LMP1 are inconsistent, these tumours are generally considered to show a type-III latency pattern, in which most EBNAs and LMPs are observed $[8,17,18]$.

One case report suggesting a possible role for Bcl-2 in the pathogenesis of EBV-SMTs noted Bcl-2 expression in $80 \%$ of the tumour cells, but this has been refuted by other authors $[12,17]$. Whilst the exact molecular drivers of neoplasia in EBV-SMTs have yet to be clearly defined, it is generally accepted that aberrations in the MTOR/Akt pathway are involved in their pathogenesis, a hypothesis supported by reports of tumours responding 


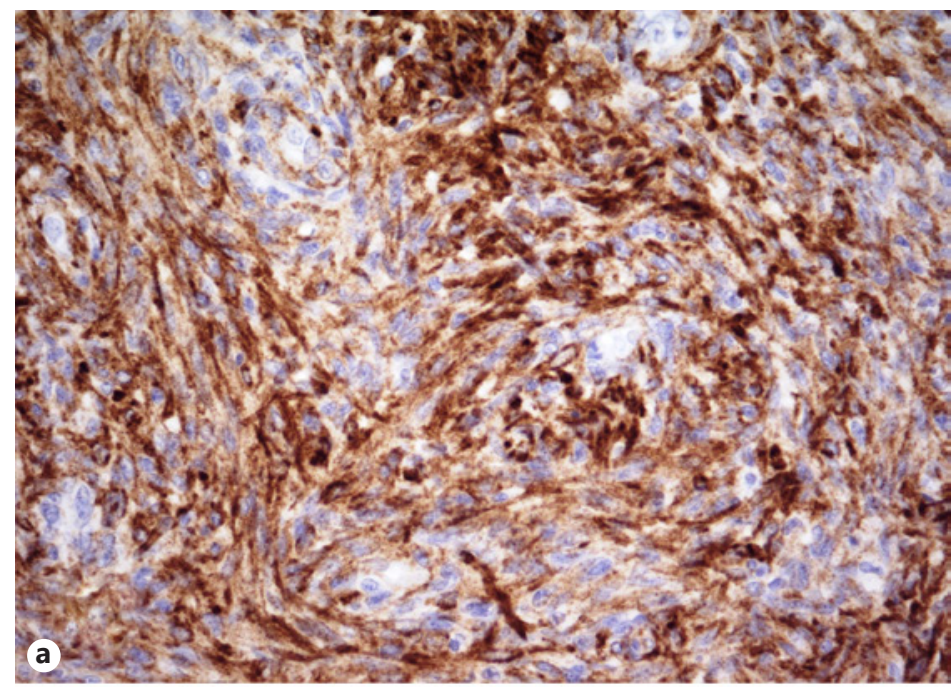

Fig. 5. Immunohistochemical staining for $\mathrm{H}$-caldesmon (a) and SMA (b). c Positive EBER-ISH in the tumour cells.
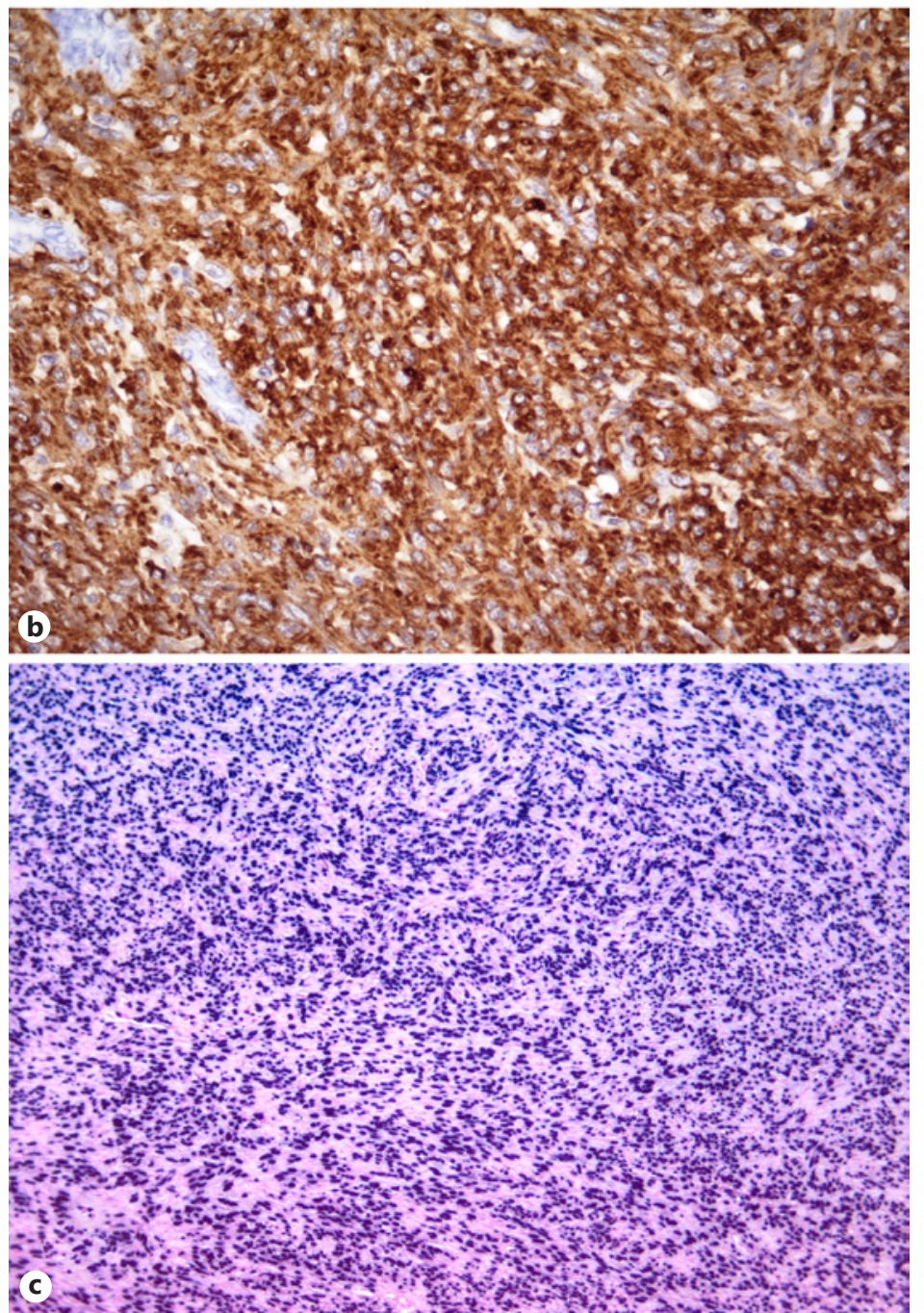
to treatment with sirolimus $[5,8,18,19]$. Over-expression of $M Y C$ proto-oncogene has also been demonstrated in some EBV-SMTs, suggesting that EBV itself may lead to up-regulation of $M Y C$. The latter, however, is not associated with a demonstrable re-arrangement of the $M Y C$ locus by fluorescence in situ hybridisation analysis $[9,18]$.

Obvious histological differential diagnoses to consider for this entity include conventional leiomyoma, leiomyosarcoma, myopericytoma, and fibrous histiocytoma, especially when a given patient's immune status is not known. As stated earlier, the aforementioned neoplasms can be readily distinguished from EBV-SMT via the use of EBER-ISH. Two additional entities, however, require consideration in the differential diagnosis of EBV-SMTs, namely, tumour-stage KS and a spindle cell pseudotumour of infective origin. Tumourstage KS in particular is a potential source of differential diagnostic difficulties since both EBV-SMT and KS may exhibit "myoid" histomorphology and contain a sprinkling of intralesional inflammatory cells. KS, however, stains with endothelial markers such as CD31, CD34, and podoplanin (D2-40) and shows nuclear positivity for human herpes virus type-8 (HHV8), whereas these immunohistochemical markers are not expressed in the lesional cells of EBV-SMTs. Mycobacterial spindle cell pseudotumour shows positive immunostaining for CD68, while histochemical staining with the Ziehl-Neelsen method will declare numerous acid-fast bacilli. A spindle cell pseudotumour of fungal aetiology is morphologically similar, and confirmation thereof will necessitate the use of appropriate histochemical stains for fungi.

The treatment and prognosis of EBV-SMTs remains the subject of relative controversy. Consequently, there is a general lack of consensus regarding how these tumours are best managed. Although one acknowledges that our study is limited by the lack of clinical follow-up data and details concerning treatment outcome, evidence from the literature indicates that these neoplasms generally have a favourable prognosis, and that the histological appearances are not predictive of tumour behaviour [4-7]. In one of the largest case series to date, mortality was recorded in only 3 patients, of whom only 1 died of tumourrelated complications [4]. This particular patient had widespread disease involving the spinal cord, gall bladder, lung, and liver. It should be noted that another 5 patients in the same study had widespread disease, all of whom were still alive at the time of most recent follow-up. Although death occurred in 17 of 25 patients in another large South African series, this was mainly as a result of comorbid diseases [7]. Aside from the tumour's unpredictable biologic potential, it would seem that those patients with a fatal outcome usually succumb to complications related to their immunosuppressive state rather than the EBV-SMT itself. Simple surgical resection is a treatment modality that has been employed with some success [20]. In their study, Hussein et al. [5] found that survival did differ significantly among 3 EBV-SMT groups (HIV-associated EBV-SMT, PT-SMT, and CI-SMT), irrespective of the completeness of excision, tumour multiplicity, tumour size, or the presence or absence of atypical features.

In summary, ours is the second largest case series of EBV-SMTs reported from South Africa to date. Although one acknowledges that the study has certain limitations, our findings do nevertheless corroborate those of other authors, including the strong association with HIV infection and a particular predilection for the cutaneous soft tissues and the CNS. Despite its relative rarity, pathologists' familiarity with the entity is important in countries such as South Africa, where there is a considerable burden of HIV disease. The distinction of EBV-SMTs from other HIV-related mesenchymal spindle cell proliferations and pseudotumours is afforded via judicious application of EBER-ISH and the use relevant immunohistochemical markers of smooth muscle differentiation. 


\section{Acknowledgements}

The authors are eternally grateful to the late Prof. Mario Altini, visiting Professor of Oral Pathology, Division of Anatomical Pathology, Faculty of Health Sciences, University of the Witwatersrand, Johannesburg, for his guidance and supervision of this study, which was undertaken in partial fulfilment of the requirements for the degree of MMed (Anat Path).

\section{Statement of Ethics}

An ethics clearance certificate (clearance number M1611147) was obtained from the Human Research Ethics Committee of the University of the Witwatersrand, Johannesburg.

\section{Disclosure Statement}

The authors have no conflicts of interest to declare.

\section{Funding Sources}

No funding was required for this descriptive study.

\section{Author Contributions}

Dr. Tirelo M. Pitjadi drafted the protocol for the study, retrieved and reviewed all the relevant pathology reports and microscopic slides, and drafted the study report.

Prof. Wayne Grayson took over as a supervisor for the study following the untimely demise of Prof. Mario Altini. He therefore supervised the analysis of the data and assisted with photomicrography and critical appraisal of the manuscript.

\section{References}

1 Pritzker KP, Huang SN, Marshall KG. Malignant tumours following immunosuppressive therapy. Can Med Assoc J. 1970 Dec;103(13):1362-5.

2 Lee ES, Locker J, Nalesnik M, Reyes J, Jaffe R, Alashari M, et al. The association of Epstein-Barr virus with smooth-muscle tumors occurring after organ transplantation. N Engl J Med. 1995 Jan;332(1):19-25.

3 McClain KL, Leach CT, Jenson HB, Joshi VV, Pollock BH, Parmley RT, et al. Association of Epstein-Barr virus with leiomyosarcomas in young people with AIDS. N Engl J Med. 1995 Jan;332(1):12-8.

4 Deyrup AT, Lee VK, Hill CE, Cheuk W, Toh HC, Kesavan S, et al. Epstein-Barr virus-associated smooth muscle tumors are distinctive mesenchymal tumors reflecting multiple infection events: a clinicopathologic and molecular analysis of 29 tumors from 19 patients. Am J Surg Pathol. 2006 Jan;30(1):75-82.

5 Hussein K, Rath B, Ludewig B, Kreipe H, Jonigk D. Clinico-pathological characteristics of different types of immunodeficiency-associated smooth muscle tumours. Eur J Cancer. 2014 Sep;50(14):2417-24.

6 Suankratay C, Shuangshoti S, Mutirangura A, Prasanthai V, Lerdlum S, Shuangshoti S, et al. Epstein-Barr virus infection-associated smooth-muscle tumors in patients with AIDS. Clin Infect Dis. 2005 May;40(10):1521-8.

7 Ramdial PK, Sing Y, Deonarain J, Vaubell JI, Naicker S, Sydney C, et al. Extra-uterine myoid tumours in patients with acquired immunodeficiency syndrome: a clinicopathological reappraisal. Histopathology. 2011 Dec; 59(6):1122-34.

8 Purgina B, Rao UN, Miettinen M, Pantanowitz L. AIDS-related EBV-associated smooth muscle tumors: a review of 64 published cases. Pathol Res Int. 2011 Mar;2011:561548. 
9 Dekate J, Chetty R. Epstein-Barr Virus-associated smooth muscle tumor. Arch Pathol Lab Med. 2016 Jul; 140(7):718-22.

10 Chadwick EG, Connor EJ, Hanson IC, Joshi VV, Abu-Farsakh H, Yogev R, et al. Tumors of smooth-muscle origin in HIV-infected children. JAMA. 1990 Jun;263(23):3182-4.

11 van Hoeven KH, Factor SM, Kress Y, Woodruff JM. Visceral myogenic tumors. A manifestation of HIV infection in children. Am J Surg Pathol. 1993 Nov;17(11):1176-81.

12 Chang JY, Wang CS, Hung CC, Tsai TF, Hsiao CH. Multiple Epstein-Barr virus-associated subcutaneous angioleiomyomas in a patient with acquired immunodeficiency syndrome. Br J Dermatol. 2002 Sep;147(3):563-7.

13 Calderaro J, Polivka M, Gallien S, Bertheau P, Thiebault JB, Molina JM, et al. Multifocal Epstein Barr virus (EBV)associated myopericytoma in a patient with AIDS. Neuropathol Appl Neurobiol. 2008 Feb;34(1):115-7.

14 Billings SD, Folpe AL, Weiss SW. Do leiomyomas of deep soft tissue exist? An analysis of highly differentiated smooth muscle tumors of deep soft tissue supporting two distinct subtypes. Am J Surg Pathol. 2001 Sep;25(9): 1134-42.

15 Kingma DW, Shad A, Tsokos M, Fest T, Otsuki T, Frekko K, et al. Epstein-Barr virus (EBV)-associated smoothmuscle tumor arising in a post-transplant patient treated successfully for two PT-EBV-associated large-cell lymphomas. Case report. Am J Surg Pathol. 1996 Dec;20(12):1511-9.

16 Jenson HB, Leach CT, McClain KL, Joshi VV, Pollock BH, Parmley RT, et al. Benign and malignant smooth muscle tumors containing Epstein-Barr virus in children with AIDS. Leuk Lymphoma. 1997 Oct;27(3-4):303-14.

17 Rogatsch H, Bonatti H, Menet A, Larcher C, Feichtinger H, Dirnhofer S. Epstein-Barr virus-associated multicentric leiomyosarcoma in an adult patient after heart transplantation: case report and review of the literature. Am J Surg Pathol. 2000 Apr;24(4):614-21.

18 Jonigk D, Laenger F, Maegel L, Izykowski N, Rische J, Tiede C, et al. Molecular and clinicopathological analysis of Epstein-Barr virus-associated posttransplant smooth muscle tumors. Am J Transplant. 2012 Jul;12(7): 1908-17.

19 Ong KW, Teo M, Lee V, Ong D, Lee A, Tan CS, et al. Expression of EBV latent antigens, mammalian target of rapamycin, and tumor suppression genes in EBV-positive smooth muscle tumors: clinical and therapeutic implications. Clin Cancer Res. 2009 Sep;15(17):5350-8.

20 Cela I, Shah NB, Bradly D, Loew J, Leslie W. An Epstein-Barr virus-associated smooth muscle tumor successfully treated with surgical resection: a case report and literature review. Clin Adv Hematol Oncol. 2010 Jun; $8(6): 423-6$. 